\title{
Iang Evangelivm Ul-Kadus Menjurat kapada Marcum
}

\section{The First Malay Gospel of Mark (1629-1630) and the Agama Kumpeni}

\author{
Lourens de Vries* \\ Vrije Universiteit Amsterdam Department of Language, \\ Literature and Communication \\ l.j.de.vries@vu.nl
}

\begin{abstract}
The topic of this article is the Malay gospel of Mark of 1629-163o that was recently discovered in the library of Lincoln Cathedral in England, a gospel translated by Albert Corneliszoon Ruyl, employee of the voc. Ruyl's gospels of Matthew and Mark are the earliest attested Bible translations in Malay. This article discusses the question of why the voc financed the printing of translations of the Bible and other religious literature in the East, what kind of Malay Ruyl used in Mark, and what kind of translation Ruyl made. Ruyl was a very pragmatic translator who used Malay religious terminology from Hindu-Buddhist, Islamic, and Catholic traditions, including the term Allah for God. Finally, this article discusses the academic and societal importance of the first Malay gospels of Ruyl, which, after many centuries, became newly relevant to Indonesian and Malaysian faith communities in the context of religious, legal, and political conflicts about the ownership of the word Allah.
\end{abstract}

\section{Keywords}

bible translation - Malay translation history - Allah - voc - Ruyl - Church Malay

* I thank Mathieu Knops, of the Koninklijke Bibliotheek (Royal Dutch National Library) at The Hague, for alerting me to the reference in Höweler and Matter 1985 that led me to the Lincoln Mark. I also thank Mrs J. Taylor of the Lincoln Cathedral Library for the many ways in which she helped me with my research in the magnificent ambience of the Lincoln Cathedral Library. Christian Gossweiler was of great help in comparing the Lincoln and Stuttgart Mark copies, and in dating the Lincoln Mark.

(C) LOURENS DE VRIES, 2018 | DOI: $10.1163 / 22134379-17401002$

This is an open access article distributed under the terms of the prevailing CC-BY-NC license at the time of publication. 


\section{Introduction}

The gospels of Matthew and Mark, translated by the Dutchman Albert Corneliszoon Ruyl in the first half of the seventeenth century, are the earliest attested translations of Bible books in Malay, and in Southeast and South Asian languages in general (Soesilo 2007). There were earlier efforts to translate the Bible into Southeast and South Asian languages. For example, the Jesuit missionary Franciscus Xaverius translated religious texts that included Bible verses into Malay in the sixteenth century (Drewes 1948:15). Ogden (2001:79) notes that Pope Benedict in 1335 mentions a Mongolian Bible. But no copies of these translations remain.

The bibliography of Dutch hymns Fontes hymnodiae Neerlandicae impressi 1539-1700 mentions a Malay translation of the gospel of St Mark by Albert Corneliszoon Ruyl, published in 1629 and kept in the Lincoln Cathedral Library in Lincoln, United Kingdom (Höweler and Matter 1985). The existence of three copies of Ruyl's Matthew of 1629 was known since the late 1980s, but the Lincoln Matthew and Mark had escaped scholarly attention. ${ }^{1}$ The Lincoln Matthew is the same as the Matthew copies in Stuttgart, Utrecht, and London (De Vries 2005). The Lincoln Mark, however, is the only known copy of the first edition of the gospel of Mark.

This article is organized as follows. First, the historical context of the Lincoln Mark is described. Then we zoom in on the Lincoln Mark, as a book and as a translation. Finally, we discuss the academic and societal relevance of these first Malay gospels, which, after many centuries, have attracted renewed attention in the context of the debate and conflicts surrounding the use of the word Allah and other religious terms of Arabic origin in the Bibles of Malaysian and Indonesian Christians.

1 Until 1989, when Dr Daud Soesilo of Lembaga Alkitab Indonesia (Indonesian Bible Society) found a copy of Ruyl's Matthew in the Landesbibliothek of Stuttgart (Soesilo 2013:174), scholars such as Swellengrebel (1974) thought that there were no remaining copies of the first Malay gospel of Matthew of 1629 (Gossweiler 2014a:21). In 1911, the Historical catalogue of the printed editions of the Holy Scripture in the library of the British and Foreign Bible Society, Vol. 2-2, edited by H.T. Darlow and Horace F. Moule, mentioned Ruyl's Bible translation into High Malay (published in 1629) as no. 6486 (Gossweiler 2014a:20). 


\section{The First Malay Gospels and the Agama Kumpeni}

The Vereenigde Oost-Indische Compagnie (voc, United East-India Company [1602-1795]; hereafter Company), called Kumpeni by Malay contemporaries, financed all Malay and Portuguese Bible translations and other religious writings until its bankruptcy in 1795 (De Vries 2009, 2014). The Kerkenraad (Church Council) of the Reformed Church of Batavia was consulted for approval of these versions. For example, the minutes of the meeting of 24 August 1648 report that Revd Heurnius had requested the voc Board to finance the printing of the 'first book of Moses translated into Malay by Mr Van Hasel' (Mooij 1929:91). ${ }^{2}$ The minutes of the meeting of Wednesday 16 November 1667 contain the decision of the Kerkenraad (Council) of the Batavia Church to accept the New Testament translation of the Revd Daniel Brouwerius, the first Malay New Testament, for publication (by the voc). ${ }^{3}$ They added the condition that he would revise certain gospel books 'to make the style of the whole New Testament one and the same.4 The minutes of that meeting also describe the primary goal of the Malay translation as 'to serve the churches in the Indies.' ${ }^{5}$ The final sentence of the minutes instructs the Revd Brouwerius to go to the voc for finance for the printing. ${ }^{6}$

It is important to understand from the outset that the voc had a firm grip on the Calvinist churches in the areas that they controlled (Niemeijer, Van den End and Schutte 2015:2). The voc financed all church activities in the East Indies and all the pastors and translators were voc employees. The voc moreover had the right to approve or reject appointments in church offices, controlled the allocation of pastors, had a representative in the church council meetings known as the commissaris-politiek, and monitored church correspondence (Niemeijer, Van den End and Schutte 2015:4). The name of the Company and its board, and not the name of the (Batavia) Church or Church Council, were prominently displayed either on the title page or on the first page

2 'het eerste boek Mosis in 't Maleisch overgeset door Sr van Hasel'. All English translations of material from Dutch sources in the article are mine unless otherwise indicated.

3 The minutes of the Batavia Church Council (as far as they had been preserved in the church archives in Batavia [Jakarta]) were published along with other source materials by J. Mooij in three volumes in 1927, 1929, and 1931. The minutes of 16 November 1667 can be found in Mooij (1927:76). I could not find references to an approval by the Batavia Church Council of Ruyl's gospels - probably because the minutes of the relevant meetings have not been preserved.

4 'om daer door het gansche nieu Testament van een en deselve stijl te doen wesen'.

5 'ten dienste van de kercken in Indien'.

6 'tot koste van de Compie sal laeten drucken'. 
of these Bibles and Bible books. The prefaces started with a very prominent reference to the Bevinthebberen, or board, of the voc, who were eloquently praised in the dedication.

The Resolutien (minutes containing their decisions and a summary of the grounds for these decisions) of the voc Board, published by Mooij (1927:1-8o), explicitly refer to the almost absolute control of the voc. The minutes of the board meeting of 10 January 1654 acknowledge that the instructions sent to the Governor General and his council in Batavia on 10 September 1650 relating to the churches 'gave the political government very wide and absolute power over the church council and the church personnel', adding that this absolute power was not put into practice. ${ }^{7}$ Since letters from Batavia requesting instructions, or letters from the Dutch Republic giving instructions, were sent with the voc ships on their long and very perilous journeys, in practice the voc Board indeed faced difficulties in exercising their power. The same minutes report that the voc Board had instructed the company lawyer to write a draft church order with respect to the appointment of pastors to be sent to the Governor General in Batavia for advice and comments.

The voc was the first company in the world to sell shares to finance its operations. Investing in voc ships and their precious spice cargo was a great risk, with potentially huge awards. This raises the question of why a company of early modern capitalists would finance the translation, printing, shipment, and distribution of Bible translations (De Vries 2005). The answer lies in the way Dutch seventeenth-century Calvinism understood the relationship between the Republic and the Dutch Reformed Church. Article 36 of the Nederlandse Geloofsbelijdenis (Dutch Confession) claimed that the State was obliged 'to protect the holy worship of the Church and to suppress and destroy all idolatry and false religion.8 ${ }^{8}$ This implied that the Republic financed the Dutch Reformed churches in the Low Countries, including the salaries of the pastors, and had a lot of influence in church matters. The faith of the Calvinist Church was the public faith. All other forms of religion (including Catholicism and Anabaptism, both labelled as false religion and idolatry) could not be present in the public domain. Privately, people of other convictions were permitted to continue practising their religion, including holding services of worship in private homes or other non-public meeting places.

7 'Dat wel waer is dat de meergemelte missive aen de politijcque Overheijt seer ample en absolute macht geeft over de kerckelijcke regieringe, en de Ecclesiastijcquen maer dat die in dier voegen niet is noch wert gepractiseert' (Mooij 1927:39).

8 'de heilige dienst van de kerk te beschermen en om te weren en uit te roeien alle afgoderij en valschen godsdienst'. 
The Dutch Republic issued charters (octrooien) to the voc that entitled the voc to a trade and shipping monopoly in the East, excluding other Dutch traders (Schutte 2002). The first octrooi was signed on 20 March 1602. The octrooi also delegated key public duties and rights to the voc, because the VOC operated in areas far beyond the control of the Republic: the right to build fortifications, to administer justice in the name of the Republic, the right to employ soldiers and engage in warfare, and the right to appoint governors (Schutte 2002:50).

One of the public duties mentioned in the octrooi of 1623 was the protection and upholding of the public faith (De Vries 2005:16-7). It implied that the voc had the duty to facilitate and finance the Dutch Reformed congregations and schools in the rather small part of the archipelago under its territorial control. The voc was interested in trade and gain, not in expanding its territorial control per se. Koolen (1993:23) points out that the reference to the protection of the public faith in the charter of 1623 (and subsequent charters) is placed in the considerans section, the introductory section, and not in the instruction section in which the legally binding rights and duties of the voc were stipulated. By doing so, the Staten-Generaal (States General, the highest authority of the Republic) made clear that it considered the duty to protect the public Reformed faith as an obvious, completely self-evident moral and religious duty for the voc in all areas under their jurisdiction. This included all voc fortified trade posts in the Far East, for example Ceylon and Formosa, where the voc financed the translation of (parts of) the Bible and catechisms (Adelaar 2011).

In the archipelago the voc-sponsored Bible translations were limited to Malay and Portuguese, because those two were the main contact and trade languages in the archipelago, and were also used in the ethnically and linguistically heterogeneous congregations of the Dutch Reformed Churches in the East. The vOC never financed Bible translations in any of the indigenous languages of the archipelago, some of which had many millions of speakers (for example, Javanese) and would have been languages that the intended audiences in the seventeenth-century archipelago would have understood far better than Malay and Portuguese. Indeed, indigenous languages only became targets for translations of the Bible by the mission societies that were founded towards the end of the eighteenth century and in the first decades of the nineteenth century in Europe and America. In fact, Javanese was the first language targeted for Bible translation by the Nederlandsch Bijbelgenootschap (Netherlands Bible Society) in the early nineteenth century (Swellengrebel 1974).

Some pastors in areas where Malay was not widely known translated religious materials into indigenous languages. For example, the bibliography of Niemeijer and Van den End (2015:153) lists translations in the indigenous lan- 
guages of Saparua by Heurnius and Sangir by Van der Leeuw. The latter translated Mark and wrote a short catechism in Sangirese. His work was not printed because the Church Council of Batavia stuck to the language policy of using the common languages Malay and Portuguese (Niemeijer and Van den End 2015:154).

The voc-related churches in Ambon, Ternate, Batavia, and other places were multi-ethnic and multi-lingual. The people who were expected to go to church were Europeans employed by the voc, formerly Catholic locals, some Chinese and Japanese, Mardijkers (descendants of migrants from India), and slaves from various backgrounds (Niemeijer, Van den End and Schutte 2015:5). The Europeans employed by the voc came from various nations, speaking different languages, especially German, but also Portuguese, French, and English. Malay and Portuguese played a key role as the lingua francas in these highly diverse voc and voc-dependent communities. The voc employees with church-related tasks had as their first task pastoral care of the multi-ethnic voc employees of European and Asian descent. The Malay and Portuguese Bible translations commissioned by the voc primarily functioned as tools to help achieve this task, as these two contact languages were known to various degrees to be the second languages of the majority of the attendants of the Reformed church services, whether European or Asian. The second function was to expand the Calvinist religion as the public faith in areas under direct voc jurisdiction, including formerly Catholic areas. Both these functions of the Malay and Portuguese voc translations aimed to fulfil the duties of the voc mentioned in the charters with the Republic.

Portuguese continued to be an important lingua franca, in and outside the church, long after the Portuguese left, until around 1800 (Swellengrebel 1974:9). Swellengrebel (1974:9) observes that slaves employed in Dutch households used Portuguese when communicating with family members, and that many Dutch children knew the lingua franca variety of Batavian Portuguese better than Dutch. The Portuguese pastor d'Almeida, a pastor of the Reformed Church in Batavia, translated the New Testament into Portuguese. The Portuguese New Testament of d'Almeida was printed in Amsterdam at the cost of the voc in 1681. The complete Bible in Portuguese appeared much later, in 1748 . This voc Bible is the first Bible in Portuguese and has been globally used in Portuguesespeaking parts of the world, especially Brazil, with a revision of 1959 still bearing the name of d'Almeida (Swellengrebel 1974:10; De Vries 2005:17).

The voc context of the first Malay Bible translations also explains why the translations were designed and printed as solid and expensive Bibles, in rather small quantities, rather than as cheap editions for small purses such as would be distributed much later by missionaries and evangelists in the nineteenth 
century. The Heeren XVII (the Lords Seventeen that governed the voc) decided on 21 August 1629 to let Palensteyn in Enkhuizen print 480 copies of the first Malay gospel of Matthew.

Ruyl writes in the preface to his first gospels, addressing the board of governors of the voc, that he wants to translate the whole New Testament into Malay for 'the expansion of our Public Christian Religion [...] to the salvation of many, simple souls who in due time will be brought safely to the lap of the Church under the protection of Your Excellences.' ${ }^{9}$ Ruyl phrases his missiological intentions using the standard terms of the Dutch Calvinism of the Republic to describe the Calvinist Church as the privileged, public religion that received the protection of the government, which was represented in Batavia by the Governor General of the voc.

The voc did not spend much money on the protection of the public Reformed faith in the East. The funds spent on church and school work, including Bible translation, formed a minor part of the total voc operation. For example, according to Schutte (2002:50) the voc employed 14, 800 persons in the Dutch East-Indies in 1688. Only 108 of these, so less than $1 \%$, were employed in church and church-related ministries, and this included 23 schoolmasters. However, only European employees are counted in these statistics, not the many indigenous guru (teachers) involved in the schools. Trade surely was the primary goal of the voc, based on establishing and maintaining trade monopolies with military means.

The Heidelberg Catechism of the Dutch Reformed Church contained the teaching that the Catholic Eucharist was 'vervloeckte afgodery' (cursed idolatry). Therefore, it was important for the pastors to bring Catholic Christians into the fold of the Dutch Reformed Church in those areas under voc control that the Portuguese (Moluccas, North Celebes) or Spaniards (Sangir-Talaud islands) had controlled in the sixteenth century (Niemeijer, Van den End and Schutte 2015:3; De Vries 2014). The voc government no doubt hoped that Protestantization would make the local population more inclined to accept their rule. The Catholic villages of these areas came under the direct authority of the VOC and they numbered around 16,ooo souls after the surrender of the Portuguese, with this figure rising by an additional 30,000 after the withdrawal of the Spaniards (Niemeijer, Van den End and Schutte 2015:3).

9 'tot voortplantinghe van onze Alghemeyne Christelijcke Religie [...] ter zalichheyt van vele arme, eenvoudighe zielen, die mettertijt gerustelijcken in de schoot der Kercke, onder U.E.A. bescherminghe gebracht sullen werden'. 
Since the gereformeerde kerk (Reformed Church) was the only form of religion tolerated in the public domain in the areas under voc control, all of a sudden there was a Dutch Reformed Church with many congregations and with thousands of formerly Catholic believers that needed catechisms, liturgical texts, and Bibles in Malay-essential tools for the Protestantization and pacification of these regions (De Vries 2014). There was a system of fines in place to punish people who did not go to church (Niemeijer 2002a:12930). It is understandable that a common Malay name for this public Christian religion was agama Kumpeni (the Company's religion) (Niemeijer 20o2b:14776). The villages that had converted to Islam in the areas under the jurisdiction of the sultanates of Tidore, Ternate, and Batjan remained under the sultans and could practise their religion unhindered (Niemeijer, Van den End and Schutte 2015:3).

The voc schools were an extension of the church, and the curriculum focused almost entirely on religious instruction. The schools also functioned as a tool of pacification (Koolen 1993). The Malay and Portuguese Bible translations and catechisms played an important role in the voc-sponsored schools. The instructional and liturgical functions are reflected in the supplementary texts that accompanied the Malay gospels of Ruyl: the liturgical section contained a few hymns and psalms, the Lord's Prayer, the Ten Commandments, the Prayer before the Sermon, the Prayer after the Sermon, the Songs of Zechariah, Mary, the Angel, and Simeon from the birth narrative in Luke, and the Apostolic Creed-all key elements of Dutch Reformed church services. Pupils in the Malay voc schools had to memorize the Lord's Prayer, the Ten Commandments, and the Apostolic Creed (Koolen 1993).

The gospels of Matthew and Mark by Ruyl in 1629-1630 were followed by the gospels of Luke and John in 1646 and Fifty Psalms in 1648 by Jan van Hasel and Justus Heurnius. The Four Gospels and Acts were published in 1651. The complete Psalter by Van Hasel and Heurnius appeared in 1652. The year 1668 saw the publication of the New Testament by Brouwerius, who had published a Genesis translation in 1662. Finally, in 1733, the complete Bible by Leijdecker was published. The voc financed all these books. There was, however, also an edition of the Four Gospels and Acts by van Hasel and Heurnius printed in Oxford for Henry Clements, with a preface by Thomas Marshall. ${ }^{10}$

10 I extracted the information on Malay translations from Niemeyer and Van den End 2015:127-69 and from Mamahit 2014:89; the latter source uses the data provided by Christian Gossweiler. 
The Malay Bible translations were part of a wider voc programme to provide churches and schools with educational and religious materials, and to provide translators and interpreters with grammatical and lexical information on the Malay language. The list of printed writings in Malay from the voc period in Niemeyer and Van den End (2015:127-69) contains translations of catechisms, ABC booklets, grammatical treatises, lexica, and sermons. Some voc merchants or pastors became Malay specialists, for example Ruyl, Leijdecker, and Werndly. They laid the linguistic foundation (vocabularies, grammars, studies of Malay literature) and translated religious literature for church and school.

\section{The Changing Place of Missionary Translation towards the End of the voc Era}

Enlightenment ideas would give religion, mission, and Bible translation a radically different place in society in the course of the eighteenth century (Van Rooden 1996; Van Eijnatten 2003). The place of the Christian religion shifted from its public, confessional, state-controlled position to that of a conviction of the heart and conscience of individual citizens. These individual citizens had the right to organize themselves independent of the state and the state church. This independent organization took the form of societies, which were legal bodies in the new middle ground of civil society. Missionary and Bible societies were formed with the aim of winning the souls of heathens, wherever they were. From 180o, Bible societies (rather than authorities of the state or the state church) became the dominant players in the translation, printing, and distribution of (non-confessional) Bibles, especially in Protestant countries and their colonies (De Vries 2016).

The organizational independence of Bible societies did not mean that the state had no influence on their policies in the colonies. The boards of the Netherlands Bible Society and the British and Foreign Bible Society had influential members that were high-ranking (former) civil servants in the colonies. The Right Honourable Lord Teignmouth, first president of the British and Foreign Bible Society and its president for 30 years, was a former Governor General of the British East India Company. Until 1819 the Dutchman Baud was general secretary of the Dutch government in Batavia (Jakarta), and an influential member of the board of the Netherlands Bible Society branch in The Hague (De Vries 2016).

Baud wrote a policy paper titled Consideratien over de vertaling en verspreiding van de Heilige Schriften (Considerations regarding the translation and distribution of the Holy Scriptures). Baud emphasizes that the Netherlands Bible Society must send the message to the colonial government that it will stay away from any proselytizing and also will keep proselytizing missions at 
a safe distance because, he says, the colonial government will only tolerate Bible society activities in the East in as far as 'the stability of beautiful and rich Java, an important source of East Indian finances for us, is not threatened'.11

Bible translation policies for the colonies were grounded in the colonial Enlightenment discourse of the Bible as a force of civilization. Gijsbert Karel van Hogendorp, the most influential and powerful Dutch politician of his day and president of the Netherlands Bible Society branch of The Hague, addressed the board of the Netherlands Bible Society in 1816 to formulate the policy goals for these translations in the languages of the East. He stated that they should not aim to proselytize, nor even have a hidden aim to do so. The Bibles to be translated and distributed in the East should aim to civilize:

'Europe' - Napoleon said [...] —-became civilized because of Christianity'. Everyone knows to what extent the Heathens are backward in terms of civilization. Also for the operation of the State therefore it can be seen as important to distribute a means of civilization. ${ }^{12}$

On the contrary, early voc translators such as Ruyl and Van Hasel were not missionaries in the sense of people sent abroad by missionary societies to win the souls of heathens, as an activity independent of the state and independent of the state-backed confessional churches (Van Rooden 1996). Rather, they were voc employees carrying out the duty of the octrooi to protect the public Calvinist religion. Ruyl was a junior merchant of the voc when he translated the gospels of Matthew and Mark (Werndly 1736). This does not imply that they or later voc pastors who performed translation work did not have any missionary zeal, or that they did not go to places outside of voc control to proselytize. Leydecker was the first pastor to receive an official commission and dedicated time for his translation work. Before his time, the translators did their work on their own initiative in their spare time, showing missionary zeal, and then presented their work to the voc to be printed and distributed. But the overall institutional context of the religious translation work

\footnotetext{
11 'De rust van het schone en rijke Java, de voorname hulpbron van onze Indische financien, niet wordt in de waagschaal gesteld.' Baud is quoted in Swellengrebel 1974:27.

12 “Europa"—zeide Napoleon [...] — "is door het Christendom beschaafd geworden". Hoe verre de Heidenen nog achterlijk zijn in beschaafdheid, weet iedereen. Ook voor de huishouding van de Staat mag het dus belangrijk gerekend worden een middel van beschaving te verspreiden.' Van Hogendorp, quoted in Swellengrebel 1974:27; see also De Vries 2016 .
} 
in this period is shaped by the notion of the Protestant faith as the public religion under the wings of the voc.

\section{The Lincoln Mark as a Book}

The Lincoln Cathedral Library has a copy of Ruyl's Malay Matthew of 1629, shelf mark Qq. 4.7, and a copy of Ruyl's translation of Mark, shelf mark Qq. 4.8 , originally bound together in one volume, with one title page. The title page contains this text:

Het nieume testament. Dat is: het Nieuwe verbont onfes heeren Jesu Chrifti in Nederduyts Ende Malays/na der Griekfcher waerheijt overgefet. $^{13}$

Iang TESTAM ENTUm BAHARV. Arti-n'ja: Iang d'jand'ji baharů dari Tůhanků Iefů Chrifti: berfalim kapada baffa Hůlanda daan baffa Malajů feperti jang Adillan baffa Gregů

Gedruckt t'Enckhuyfen/ by Jan Jacobsz Palensteyn/opt Suyd-eynde inde druckery/1629.

Ber-pra-tfiap ka Nagri Enkhůfen, pada Iůhan Iacůb, Menaůn ka ůdjůng falatan dalam kedey bar-pra. 1629. ${ }^{14}$

The Lincoln Mark is in quarto format, with two columns on each page (folium). The book has 120 folia, containing the quires (katernen) A-P, subdivided into four sections (A, Aij, Aiij, Aiiij, et cetera). Folium 1 has the title in Dutch, Het H. Evangelivm beschreuen door Marcum, above the left column, and the Malay title, Iang Evangelivm Vlkadus, Menjurat kapada Marcum, above the right column of folium 1 (see Figure 1). At the end, on folium 120, below the Dutch column, it says Eynde des Evangeliums Marci and below the Malay column, Sưdahan Evangelium Marcum. The left column has the Dutch DeuxAes translation of Mark, in Gothic script and the right column has the Malay translation, in Roman script (see Figure 1), just as the translation of Matthew

\footnotetext{
13 'The New Testament. That is, the new covenant of our Lord Jesus Christ translated into Dutch and Malay after the Greek truth.'

14 'Printed in the town of Enkhuizen, by Jan Jacobsz, residing at the south end in the printshop.'
} 
(Soesilo 2001a:46-7). The Deux-Aes Bible of 1562 was the Dutch translation most used by Protestants before 1637, when the Dutch Authorized Version, the Statenvertaling, was published. The paratext of the Lincoln Mark follows that of the Deux-Aes version of the left column, with pericope titles above each chapter. The chapter number is mentioned in the left top part of the page and the page number on the top right part. Under each column we find a signature mark and a catchword (see Figure 1). The Lincoln copy of Mark is one of the first books printed in Malay.

The Mark copy in Lincoln is different from the Mark copy of the 1638 edition kept in Stuttgart. The Lincoln Mark is unique: it is the only extant copy of Ruyl's first Malay Mark in its first edition. The text, spelling, layout, and typographical details of the Lincoln Mark (1629/1630) and the Stuttgart Mark (1638) are different. For example, the decorated initial capital letter I of Mark 1:1 (see Figure 1) is different in the two Mark editions of Lincoln and Stuttgart. ${ }^{15}$ The Lincoln Mark uses the tilde sign over vowels to indicate nasals, where the Stuttgart Mark uses the letters $m, n g$, and $n$. For example, in the Lincoln Mark 1:40 we find saurãg 'a person', daã 'and', and hãba 'hamba' versus Stuttgart Mark saurang, daan and hamba. But the Lincoln Mark also sometimes writes daan. The spelling used by Ruyl and other voc translators is very inconsistent from a modern perspective. However, the spelling of Dutch in the seventeenth century was also inconsistent and not yet fully standardized in the young Republic. Ruyl and the other voc translators followed the spelling conventions of Dutch and Portuguese in writing Malay (Swellengrebel 1974).

The spelling idiosyncrasies, typography, and layout connect the Lincoln Mark very clearly to the Matthew of 1629 , and indicate that Ruyl's Lincoln Mark was printed either in 1629 or shortly after 1629 , when Palensteyn printed Matthew (Gossweiler 2014a). In the preface to what he thought would become his New Testament, Ruyl refers to his Malay grammar and word list Spieghel van de Maleyshe tale, published in 1612, to explain the vowel system of Malay, especially what Ruyl calls the diphtonghe o.u., which he spells with an $u$ that has a small circular sign on top: $\stackrel{\circ}{u}$ (see Figure 1). This $\stackrel{\circ}{u}$ is a peculiarity of the early Ruyl. We find it only in his first Matthew and Mark, not in the Stuttgart Mark edition of 1638 , nor in any other Malay publication by Ruyl or anyone else, either before or after $1629 .{ }^{16}$ Another significant spelling idiosyncrasy shared by the copies of Matthew (1629) and the Lincoln Mark, but not found in the Mark of 1638 , is the Dutch trema, or vowel separation, sign used on the letter $a$ when it

15 Personal communication with Gossweiler, 25-01-2014.

16 Personal communication with Gossweiler, 25-01-2014. 


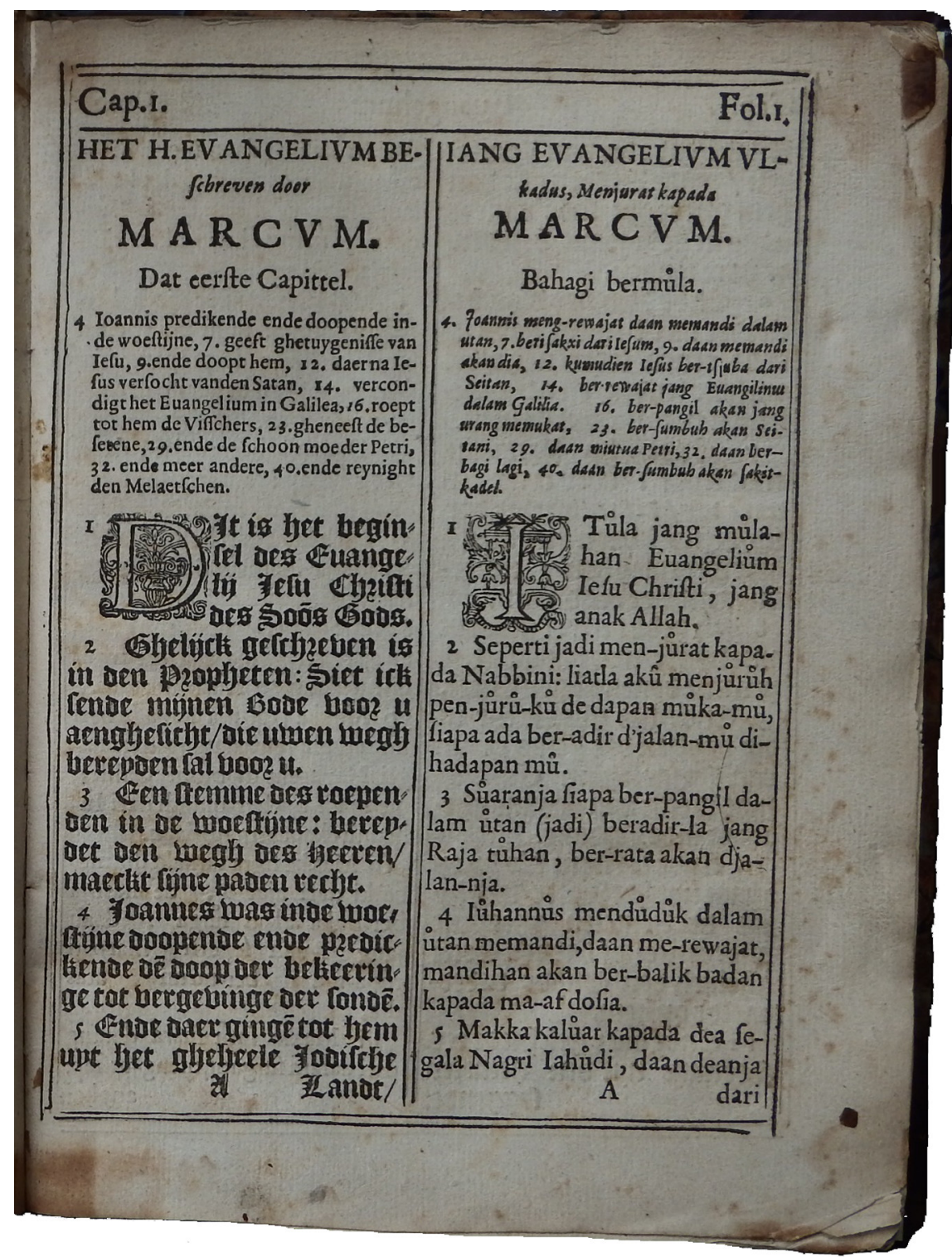

FIGURE 1 The first page of the Lincoln Mark

follows an $i$, for example tiäda, liätla. ${ }^{17}$ Ruyl writes in his preface that he finished Matthew in 1612; since he planned to translate the whole New Testament, he

17 Personal communication with Gossweiler, 25-01-2014. 
would have proceeded with the second book of the New Testament after 1612 . Both manuscripts must have been ready for printing in 1629 .

The VOC was in fact a conglomerate of six local trading companies in the major ports of the Republic. These local companies united under the umbrella of the voc under considerable political pressure of the Staten-Generaal of the Republic (Schutte 2002:50). The local companies were called kamers (chambers) and Enkhuizen was one of these voc chambers (Schutte 2002:50).

Palensteyn, the printer mentioned on the title page, owned a theatre in Enkhuizen in which plays were performed. Theatre audiences could follow the plays by buying a copy of the script of the play printed in his print shop. ${ }^{18}$ But Palensteyn did not have the expertise or skills needed to print books in non-European languages, skills that were available in Amsterdam. This is the reason that here are numerous printing errors in the first edition, forcing Ruyl to include a long list of letter faulten (printing errors). The list of errors begins with the title page, which contains the printing mistake bersalim; this should be bersalin. In later editions of his gospels these errors were corrected. ${ }^{19}$

The letter $\mathrm{M}$ is handwritten in the top left corner of the Lincoln title page that preceded the gospel translations. It is the signature of the owner, Michael (M) Honywood (1597-1681), who became Dean of Lincoln Cathedral in 166o. He was an avid book collector and signed his books with M. ${ }^{20}$

It is very likely that he bought the Malay books of Matthew and Mark in the Dutch Republic, because Honywood went to Utrecht in 1642 and stayed there for a couple of years, during the Protectorate (Venables 1885). The Malay gospels that Honywood bought ended up in the Lincoln Cathedral Library after his appointment as Dean of Lincoln Cathedral in 166o. He collected Bibles in various languages, but was also interested in many other subjects, as is clear from the magnificent collection in the Lincoln Cathedral Library.

The Malay gospels that he purchased must have had earlier Dutch owners and must have been used in the East, because on an empty page that follows the Malay translation of the Lord's Prayer on folium 38 we find these handwritten notes in the Lincoln Matthew:

tekst den 9 Julij 1639

psalm 130

djikalou tuanco mau bilang dosa

\footnotetext{
18 Personal communication with A.A. den Hollander, 2002.

19 Personal communication with Gossweiler, 25-01-2014.

20 Personal communication with Taylor, August 2013.
} 
siappa bole tingal badiri

adapan tuan ${ }^{21}$

den 23Julij 1639 tekst Jone $i-2$

itou bacattahan deos jadij

capada Jona (Yang Annac Amithai) babounji begitou

badirila dan bedjalan dalam

Yang bandar besar ninive

Lagi adjarkan di dalam

Carna dia orang pounja dosa

Souda naic capada $\mathrm{Aco}^{22}$

30 dito tekst matt 4 vers 17

Touwarkan hatij camou, carna

Jang alam surga souda ampir ${ }^{23}$

Most probably a Dutch voc pastor or schoolmaster wrote down the verses from Scripture that he wanted to preach or teach about in 1639 on 9 July (Psalm 130), 23 July (Matthew 1:2) and 30 July (Matthew 4:17). The Malay Scripture verses from Matthew 4:17, handwritten on folium 38 of the Lincoln Matthew in the liturgical folia after the gospel translation, do not come from Ruyl's Matthew, because Ruyl translated this verse as Berbaikibadan mu karna hokkum-sorga-ni ampir datang. ${ }^{24}$

\section{The Lincoln Mark as a Translation}

\section{Malay-But Which Malay?}

In 1612, fifteen years after the first Dutch ships had reached Java, Albert Corneliszoon Ruyl finished the manuscript of his Malay translation of the gospel of Matthew. The year before, he had published his Malay translation of a short

21 'If you, O LORD, should mark iniquities, O Lord, who could stand?' (English Standard Version).

22 'Now the word of the LORD came to Jonah the son of Amittai, saying, "Arise, go to Nineveh, that great city, and call out against it, for their evil has come up before me".' (English Standard Version).

23 'Repent, for the kingdom of heaven is at hand' (English Standard Version).

24 Literally, 'Make good your body (= yourself) because the heavenly jurisdiction (= kingdom of heaven) is almost here'. 
catechism that summarized the doctrines of the Dutch Reformed Church (Kort begrip van Marnix van St. Aldegonde) (Boetzelaer van Asperen en Dubbeldam 1941:30). Ruyl had learned Malay in Patani, where Malay was an indigenous language, and had been exposed to literary and court Malay, which he also tried to use in his translation (Werndly 1736; Swellengrebel 1974). The Malay that Ruyl uses in his translation is in fact a form of (emergent) Kerck-Maleis, the Church Malay variety that arose in the context of multi-ethnic and multilingual Protestant voc communities in religious genres such as catechisms, Bible translations, and sermons. It was a form of Malay also shaped by the first languages of its users and by the features of the Dutch religious texts that were translated.

The interference from the Dutch language in Ruyl's Malay is rarely lexical. There are almost no words of Dutch origin in his Malay gospels, and this is generally true for the voc translators (see Collins 2002 for Brouwerius). However, since he translates the Dutch text rather literally, there is considerable interference from Dutch grammatical patterns. For example, Ruyl often uses the marker of relative clauses yang to render the Dutch definite articles de and het in his Dutch source text, for example, in the noun phrase Iang Evangelium Ul-kadus menjurat kapada Marcum 'the Holy gospel written by Mark' in the title of Mark and in Mark 1:15 jang waktư jadi pưtưs, daan jang Radjat Allahi ampir datang 'the time is fulfilled and the kingdom of God has almost come'.

Most voc translators, including Ruyl, backed by the voc leadership, wanted to use higher varieties of Malay as found in Malay literary traditions, varieties less bound to regional spoken forms of Malay, but very difficult to understand for the vast majority of the intended users. Ruyl, in his preface, refers to this debate and to the support he received from the voc Board in Amsterdam to use what Ruyl called Hoofs Malays 'Court Malay' of a variety he found in the literary tradition of Malay: a high form of Malay used in courts and in written texts of the high type (religious treatises, court chronicles, poetry).

In his preface to the Lincoln gospels Ruyl mentions that some critics found his Malay 'al te Hoofs Malays' (rather too courtly a form of Malay) and he criticizes the Matthew translation by Van Hasel because hem ontbreeckende het lezen en schrijven van de Malayse boecken' (he lacked experience of reading and writing Malay books). Van Hasel's Malay Matthew was never printed, because the voc Board sided with Ruyl. Van Hasel was a junior voc merchant, just like Ruyl. He arrived in the East Indies in 1613. Although his Malay Matthew did not see print, his translations of Luke and Acts, lightly revised by the Revd Heurnius, were printed together with Ruyl's gospels in 1651 (Swellengrebel 1974). 
The Malay translations of Ruyl must have been very difficult to understand in most, if not all, parts of the archipelago. Many people in and around the voc stations only spoke somewhat limited forms of Low Malay, as used in trade and interethnic contact situations, if they spoke Malay at all. Such Melayu Pasar (Market Malay) varieties functioned in a limited number of contexts, with a limited vocabulary and strongly reduced verbal morphology.

In the course of the seventeenth century, children in the Christian villages of Ambon grew up learning the local varieties of Malay, and this local Ambonese Malay became the first language of more and more people. Thus it developed into a relatively stable language with its own grammar and lexis, and is still spoken today (Collins 2002). Having seen that these Ambonese Christians did not understand the Malay of Ruyl, Van Hasel, and Brouwer, pastor Valentijn began to translate the Bible into a Malay variety much closer to Ambonese Malay in grammar and lexis. His work was not accepted for printing by the Batavia Church Council, but fragments of his translation have survived as quoted Scripture in a book titled Ichtisaar, printed in 1725 , a catechism written by Dutch pastors and translated into Malay by Valentijn. ${ }^{25}$ Pastor Valentijn wrote a passionate response to his critics in the form of a pamphlet printed in 1698, defending his choice of Ambonese Malay on the grounds of understandability. ${ }^{26}$

Unfortunately, even the few people who could read or understand the High Malay of the literary traditions, both religious and secular, would find the Church Malay used in the voc translations hard to follow, because Ruyl and the other voc translators did not (and probably could not) write in the style of the Malay literary tradition. Instead, Ruyl wrote Church Malay, with interference from the syntax of his Dutch sources, with neologisms, with mistakes in the use of the all-important verbal affixation of Malay, and with a specific and unfamiliar lexis to denote theological concepts.

A letter from the Church Council of Ambon to the Church Council in Batavia of 18 September 169 o shows that sixty years after Ruyl's first gospels had been printed, understandability and the form of Malay to be used were still very much unsolved issues. ${ }^{27}$ The letter complains about the many problems and shortcomings of the congregations in and around Ambon, and sums up the

\footnotetext{
25 These fragments of Valentijn's Scripture translation can be found in Niemeijer and Van den End 2015:165-9.

26 The brochure, titled Deure der waerhijd (Door of truth), was published in Niemeijer and Van den End (2015:149-87).

27 The letter can be found as document 253 in Niemeijer and Van den End (2015:1). The handwriting of this letter is attributed by Niemeijer and Van den End (2015:1) to Revd Petrus van der Vorm, one of the language specialists of the Church.
} 
causes of that deplorable situation: there are too few pastors, there are not enough Malay Bible books, and even if there are Malay translations, they are not very effective. The letter explains: 'One should not think that the Malay language is a general language here. Many natives, especially on the outer islands, do not know Malay at all. Most of them understand just enough for the needs of daily life. 28

The letter goes on to observe that even the few people who know Malay at the level of the literary traditions do not understand the Church Malay of the Bible translations. That form of Malay, although it has been borrowed 'uyt de eygene boeken der regte Maleyers' (from the own books of the proper/true Malay people), has been modified 'tot't gebruyk van onse Christelijke Theologie' (to the use of our Christian theology). About this Church Malay the letter states: 'It would be desirable if they could understand that language; we mean the Christians. The Muslims are not much better, although some of their scholars know the proper Malay, and also Arabic, or at least they should know given their so called religion.'29

Around the turn of the century, Malay specialists such as Revd Melchior Leydecker and Revd Petrus van der Vorm looked back at the results of the work of the pioneers Ruyl, Van Hasel, Heurnius, and Brouwer and realized the shortcomings of their work. In a letter of the Batavia Church Council of 15 November 1697, the writer (probably Leydecker; see Niemijer and Van den End 2015:135) points to many mistakes in the older versions and writes 'that the gentlemen Ruyl and Hasel, uneducated persons, have gone astray in this respect is no wonder, but that first D. Heurnius and afterwards both D. Brouwerius and the Englishman Thomas Marshall did not see these mistakess remarkable. ${ }^{30}$ The letter writer does not blame the voc merchants Ruyl and Van Hasel for their mistakes, because they were, after all, people without higher education. This strengthens the likelihood of the idea that Ruyl did not translate from a Greek

28 'Men moet niet meenen dat de Maleitse taal hier een algemeene taal is. Veel Inlanders zijn er, voornamelijk op de buiteneylanden, die gants geen Maleits kennen. De meeste onder haar verstaan maar soveel als se tot haar dagelijkse ommegang van nooden hebben.'

29 'Maar't was te wenssen dat d'Inlander dese taal verstont; we spreken van de christenen. De mooren zijn niet veel beter, hoewel er buyten twijffel onder die enige van haar geleerden zijn die de regte Maleitse taal, ook wel d'Arabische, kennen, of tenminste behoorden te kennen, ten opsigt van haare soogenaamde godsdienst.'

30 'Dat de heeren Hasel en Ruyl, ongestudeerde persoonen, hierin hebben gedwaalt is geen wonder, maar dat eerst D. Heurnius [...] en naderhand D. Brouwerius, alsook den Engelsman Thomas Marshall, dit niet hebben gesien [...] is te verwonderen' (Niemeijer and Van den End 2015:142). 
source text, although the title page that preceded Ruyl's gospels claims that the Malay translation is based on the Greek text of the New Testament (sepertijang Adillan baffa Gregü). His translation of Matthew and Mark follows where possible the Dutch text of the Deux-Aes translation found in the left column of his diglot gospel translations, and not the Greek text. The claim that the translation is based on the Hebrew, Greek, or Aramaic source texts is found on the title pages of most Protestant translations from the sixteenth and seventeenth centuries to signal that it is a Protestant Bible, not based on the Latin Vulgate (Gossweiler 2014b:75).

To substantiate his harsh judgement the writer of the Batavia Church Council's critical letter of 15 November 1697 presents various kinds of evidence. For example, he points to the Malay translation of the herbal plant munte (mint) as derham 'money' in Brouwerius's New Testament in Matthew 23:23, where Brouwerius had followed Ruyl. ${ }^{31}$ Indeed, Ruyl (and Brouwerius) use the Malay loanword draham (based on the plural form of the Arab derham, draham-in) in this verse. The Dutch word for the garden plant munte 'mint' has the homonym munte, meaning 'coin; money'. Thus Ruyl mistranslated munte according to the meaning of the Dutch homonym (money, coinage) as the noun draham 'money', which had entered the Malay language through the influence of Arab traders, who in turn had borrowed it from the Greek drachme (as the learned writer of the critical letter of the Batavia Church Council observes). If Ruyl had made his translation directly from the Greek source text, he would not have made this mistake. Ruyl could only have made that mistake because his source was the Dutch version with the homonym 'munte', and he clearly did not understand the Dutch version in which the three types of herbal plants are mentioned. The writer of the letter wonders why the more learned revisors of Ruyl (the pastors Heurnius and Brouwerius, who were supposed to read Greek) did not catch such obvious mistakes.

\section{Daring Translation Strategies}

Ruyl permits himself a number of striking liberties that a Calvinist Bible translator at home in the Dutch Republic would not have taken. First of all, the frequent use of Hindu-Buddhist, Islamic, and Catholic religious terminology, even for key terms such as 'God' or 'the Holy Spirit'; second, the use of cultural substitutes; and third, neologisms. These three features were the result of his

31 New Revised Standard Version: 'Woe to you, scribes and Pharisees, hypocrites! For you tithe mint, dill, and cummin, and have neglected the weightier matters of the law: justice and mercy and faith.' 
pragmatism, a pragmatism that he shared with many other voc men who had to adjust to conditions and circumstances that were very different from those in their home countries in Europe.

\section{Hindu-Buddhist, Islamic, and Catholic Religious Terminology}

In order to find Malay terms for religious concepts such as God, priest, sacrifice, baptism, and holiness, but also for concepts of the biblical worlds unfamiliar to most Malay speakers (words such as snow, desert, winter, and summer, and various types of animals, plants, and trees), Ruyl had to use the full breadth of the Malay language in creative ways, using neologisms and Malay loanwords from other languages.

Since Hindu-Buddhist, Islamic, and Catholic notions had entered the Malayspeaking world before Protestantism, Malay had borrowed religious terms from the holy texts in the languages associated with these religions: Indic languages, Arabic, and Portuguese. All voc translators used words such as pandita (modern Malay pendeta 'pastor') and dewa 'deity' (used to refer to 'false' gods in voc translations) from Sanskrit, words such as Allah 'God', imam 'priest', nabi 'prophet' from Arabic, and words such as Deos 'God', Babtista 'Baptist' and Spirito 'Spirit' from Portuguese. voc translators applied such Malay words, borrowed from the languages of what they saw as 'false religions', in different ways, sometimes even using both Portuguese and Arabic Malay loanwords for the same Hebrew or Greek term; for example, Alla 'God' and Deos 'God' in the translation of Hebrew Elohim in Genesis 1 of Brouwerius (1662), where the Hebrew has only Elohim 'God' in Genesis 1 (De Vries 2005).

Ruyl seems to prefer Arabic-based Malay religious terms over Portuguesebased or Sanskrit-based ones in his Malay translation; for example, he uses Allah rather than Deos for God, and Ruah rather than Spirito for Spirit. Had he learned Malay in Ambon, he probably would have used more Portuguese loanwords, since Ambonese Malay uses many words of Portuguese origin. We find Allah in the very first verse of the Lincoln Mark (Figure 1). Ruyl is the first to write the word Allah in roman script in Malay literature: 'Itůla jang můlahan Evangelium Iesu Christi, jang anak Allah' (The beginning of the gospel of Jesus Christ, the Son of God; King James Version).

Some other Arabic-based religious terms used to denote biblical notions in the Lincoln Mark are: ůlkadüs 'holy', Beitul Allah 'temple' (= House of God), Růah-ůlkadi̊s 'Holy Spirit', nabbi 'prophet' and the plural nabbini 'prophets', mumin 'blessed' (as a translation of Dutch salich), rahmad 'mercy', haramzada 'sinner', umat 'congregation; religious community', malaikat 'angel'; korban 'sacrifice'. This does not mean that Ruyl always avoids Malay words derived from Portuguese. He seems to use them especially when seeing no alternative for the 
Portuguese word; for example, in Mark 10:21 he chooses the Portuguese loan krus 'cross' where the Dutch in the left column has cruyce 'cross', and in Mark 5:12 he uses sinagugo 'synagogue'. Ruyl uses the Malay neologism mandihan in I iannes mandihan 'John the Baptist' in Mark rather than using the Portuguese loanword babtista that he used in his translation of Matthew (where he used both Iúannes mandihan and Iúannes babtista to translate the phrase John the Baptist).

\section{Cultural Substitutes}

The second pragmatic characteristic feature of Ruyl's translation is his use of cultural substitutes for biblical realia that were unknown or unfamiliar to Malay-speaking audiences and for which he assumed there was no Malay equivalent. The sandy, dry deserts of Palestine are rendered by Ruyl as utan 'forest' or rimba 'jungle.' The snow in Mark 9:3 is rendered using the cultural substitute umbun 'white vapour, steam, dew'. The winter mentioned in 13:18 becomes musim udjan 'monsoon, rainy season' and the summer of Mark 13:28 is musim kamarauw 'dry season'.

In Mark 2:23 it is narrated how the disciples of Jesus began plucking ears of grain while travelling on a Sabbath. Ruyl uses the cultural substitute padi 'rice' for the wheat (or barley) mentioned in the Greek original (and in the Dutch translation), turning the fields of wheat into rice fields. To use a cultural substitute in what was seen as a historical narrative was a daring form of pragmatism from a Calvinist perspective, because it changed the 'truth': Jesus and his disciples walked in the rice fields in Ruyl's version. The fact that the Malay translation is part of a diglot with the authoritative Deux-Aes text in the left column made it easier to use such daring translation strategies. The Malay column is not presented as a stand-alone text, but as a dependent text, a parallel text, perhaps even as an explanatory translation.

\section{Neologisms}

The third pragmatic feature characteristic of Ruyl is his use of neologisms. For example, the biblical genre of the parable, ghelijckenisse in the Dutch text in the left column, is rendered sometimes by sepertihan, a calque from the Dutch term $($ seperti $=$ ghelijck [like, as, same];

an = enisse [-ness]) and in other verses as artijan, a neologism based on the Malay root arti 'meaning, interpretation' and the derivational suffix -an. Ruyl continues the strategy of neologisms that he already introduced in his translation of Matthew (Soesilo 2014:65). For example, in Mark 1:4 (see Figure 2), Ruyl uses the neologism ber-balik badan 'to turn the body', a neologism based on bekeeringe 'turn' in the Deux-Aes. 


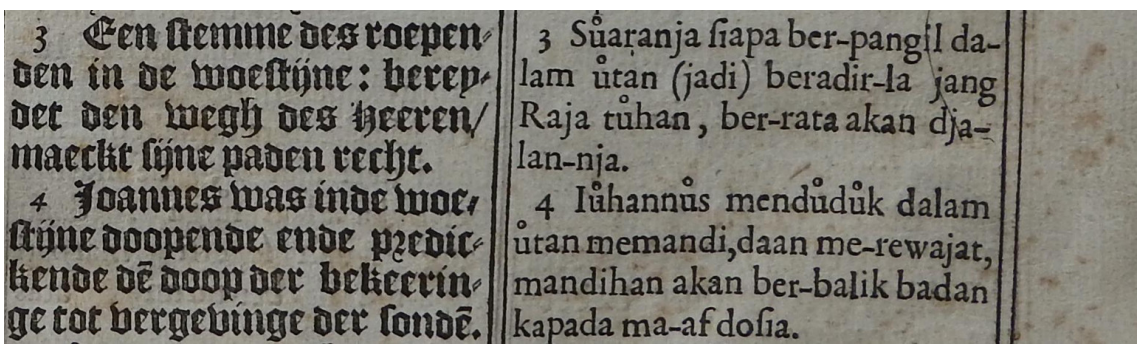

FIGURE 2 Mark 1:3-4 in the Lincoln Mark

Gossweiler (2014b:78) points out that the choice of the neologism ber-balik badan 'to turn the body' for the Greek metanoia 'conversion' as used in Mark 1:4 was connected to one of the main themes of dispute between Catholics and Protestants in the era of the Reformation: the issue of the basis for salvation and forgiveness of sins. Dutch translations made by Catholics and approved by the Bishops followed the Vulgate and used the Dutch loanword penitencie 'penitence'; for example, in the Leuvense Bijbel, based on the Vulgate rendering of the Greek metanoia 'conversion' as paenitentia. Calvinist translations avoid the use of the word penitencie because it was too closely associated with the presumed Catholic notion of atonement for sins by acts of penitence on the part of the believer: only Jesus could atone for our sins by his death on the cross. Therefore, Protestant translations use bekeeringe (literally, 'a turning around') for the Greek metanoia. Ruyl's neologism balik badan 'turn around' (literally 'turn [your] body around'), a calque of bekeeringe, was revised by Heurnius (who knew Greek) and became berbalik hati 'turn the heart' (see, for instance, Matthew 3:8), which was closer to the Greek. Heurnius revised the gospels of Ruyl (Matthew, Mark) and Van Hasel (Luke, John) to integrate them in his Malay edition of the Four Gospels and Acts of 1651 (Gossweiler 2014b:78).

\section{Relationship of the Lincoln Mark to Ruyl's Earlier Work}

As is clear from the second page of the Dutch preface to the Matthew Gospel, Ruyl had already produced a manuscript of the Malay translation of Matthew in 1612 that was criticized by some as being 'al te Hoofs Malays', that is, too courtly a form of Malay. Other first fruits of Ruyl's translation efforts in the domain of religious literature were liturgical texts related to baptism and marriage, a catechism by Marnix van Sint Aldegonde, and an $A B C$ boeck to be used in the voc schools to teach children to write, all published in the first decennium of the seventeenth century. The printing of these texts was financed by the VOC, as Ruyl writes in his preface to the Spiegel van de Maleysche tale published in 1612. The Spieghel contained didactic and uplifting material in the 
form of children's dialogues, a Dutch-Malay wordlist, and also Malay translations of the Apostolic Creed and two texts from the Bible which played a key role in the liturgy of the church services: the Ten Commandments and the Lord's Prayer. The Spieghel is a diglot edition with the Dutch text and wordlist in the left-hand column and the Malay version in the right-hand one.

Let us first have a look at the relationship between the Lincoln Mark and the few short Bible fragments found in the Spieghel van de Maleysche Tale and then look at the relation between Ruyl's Mark and Matthew.

Unfortunately, the Lord's Prayer is only found in Matthew and Luke, not in Mark, and the Ten Commandments is found in Exodus 20. This makes a comparison between the Malay of the Lincoln Mark with the Malay of the Spieghel problematic. Mark 10.19, in which Jesus mentions sections of the Ten Commandments, has been rendered by Ruyl as:

Angkau tiada batsiumbo (seventh commandment); angkau tiada memunoh (sixth commandment); angkau tiada mantsjuri (eight commandment); angkau tiada beri sakxi dusta (ninth commandment); angkau tiada beri sajang akan barang-urang (tenth commandment); angkau beri hormad akã Bappa daan ibumu (fifth commandment)

The version of some of the Ten Commandments found in the Spieghel:

Kamu memberi hormad akan bappa daan ibumu (fifth commandment) You (shall) give honour to your father and mother.

D'jang-an angkou memunoh ourang (sixth commandment)

Do not kill people.

D'jang-an angkou bersondel (seventh commandment)

Do not commit adultery.

D'jang-an angkou mantsuri (eight commandment)

Do not steal.

D'jang-an angkou bersakxi dusta de hadapan amsaja-mu (ninth commandment)

Do not give false testimony against your neighbour

D'jang-an angkou berhendak Ruma amsaja mu (tenth commandment)

Do not covet the house of your neighbour

Inasfar as we can say anything on the basis of these few and partially corresponding texts from the Spieghel and Mark, the earlier renderings in the Spieghel seem to be somewhat closer in form to formal and written Malay. The Ten Commandments in Ruyl's Mark seem to show some efforts to accommo- 
date the criticism that his Malay was 'too high'. For example, the prohibitions in the Spieghel have the standard written prohibitive Malay construction that uses the negative imperative adverb jangan, in contrast with the more colloquial spoken form that uses tiada in Mark. Lexically, the register of beri sajang akan in Mark is lower than berhendak, and sajang occurs with higher frequency in contexts of desire and longing.

A comparison of the Lincoln Mark with Ruyl's Matthew shows that Ruyl tried to be a more consistent translator in Mark than he had been in Matthew (De Vries 2002, 2009), especially where it concerns terms of theological significance. For example, in Matthew, Ruyl uses four Malay nouns to render the word 'kingdom' (Coninckrijck in his Deux-Aes source text, basileia in Greek, a noun derived from basileus 'king'): radjat, hokkuman, sultanu, and makuta (De Vries 2002:5). Since the notion of the kingdom of heaven is a theological leitmotif in the gospel of St Matthew, as the kingdom of God is in St Mark's, Ruyl's variation in renderings of the phrase 'kingdom of heaven' in Matthew is striking. He uses radjat surga (kingdom of heaven), radjat surgani (heavenly kingdom), hokkuman surgani/hokum-surgani (heavenly jurisdiction), sultanu surga (sultanate of heaven), sultanu surgani (heavenly sultanate), makuta sultani (heavenly [territory of] the crown) (Soesilo 2013).

The translation of 'kingdom' (of heaven, of God) divided Catholic and Protestant translators in the sixteenth and seventeenth centuries (Gossweiler 2014b:76). Catholic translations into Dutch followed the Vulgate regnum and translated that with rijck (for instance, the Leuvense Bijbel), but Protestant translations such as the Deux-Aes (which Ruyl followed) translated with Coninckrijck (= Coninck-rijck, King-dom) because the Greek has basileia, referring to the notion of king (Protestant ad fontes: [back] to the sources).

It could well be that Ruyl received criticism in relation to his inconsistencies in Matthew, or that he was more experienced by the time he translated Mark (or both), since he consistently uses Radjat Allahi 'godly kingdom' in his Malay gospel of Mark. And when Revd Heurnius revised Ruyl's Matthew in $165_{1}$ to integrate it in the edition of the Four Gospels and Acts, he used raidjat Allah and radjat Allah consistently, with a rare exception in Matthew 3:2, where we still find sultanu sorga (Gossweiler 2014b:77).

Although the internal consistency (within the Lincoln Mark) improved to a certain degree in his second gospel, Ruyl's Mark is remarkably inconsistent with his translation of Matthew, even in parallel passages. For example, Matthew 24:32 and Mark 13:28 are (almost) the same in his Dutch source text (DeuxAes) and in the Greek, but Ruyl translates the parallel passages in two very different ways in Matthew and Mark. For example, the Dutch Deux-Aes left column in Ruyl's Matthew has for Matthew 24:32: 'Leert van den vijgeboom 
een gelijckenisse: als nu zijne tacken teer worden, en de bladeren uytspruyten dan weet ghy dat de somer by is.' (Learn from the fig tree a parable: when its branches become tender, and leaves come forth, you know that the summer is near.) Ruyl's Malay Matthew has this in the right column: 'Aid'jerla dari půhoon pisang sawatů sapertihan: manakala dahan nja lůmbůt, daan daun'ja bertůbůh, makka taumů můnsim angat mampir.' (Learn from the banana tree a parable: when its branches become tender, and its leaves grow, then you know that the warm season is close.) And in Mark 13:28 in the Deux-Aes left column in Ruyl's Mark: 'Leert een gelijckenisse van den vijgeboom: als zijn tacken sappich werden, ende dat hy bladeren ghewint, so weet ghy dat de somer naby is.' (Learn a parable of the fig tree: when its branches become juicy, and he gains leaves, then you know that the summer is near.) Ruyl's Malay Mark in the right column: 'Aid'jerla sawatů sepertihan dari pohon kassema: tatkala tjsiabang nja menjadi lombot, daan jang daun ija kaluar, makka tau kamů jang munsim kemarauw půn mampir.' (Learn a parable from the diospyros kaki tree: when its branches become soft, and its leaves come out, then you know the dry season is close.)

The lexical differences between the parallel verses in Matthew 24:32 and Mark 13:28 are striking. Ruyl uses the banana tree as a cultural substitute for the fig tree in Matthew, but the kassema tree (= Diospyros kaki, a tree bearing sweet fruit) in the parallel passage in Mark. The rendering of summer also varies: warm season in Matthew, dry season in Mark. The branches are dahan and they bertubuh (grow) in Matthew; the branches are tsjiabang in Mark, where they kaluar (come out). Also in terms of spelling and function words we see the strong tendency of variation and inconsistency, both within books and between books.

When Ruyl's Matthew and Mark were integrated with Van Hasel's Luke and John in the 1651 Voc edition of the gospels and Acts, the differences between the Malay gospels of Ruyl and Van Hasel are striking. Heurnius, the editor of the 1651 edition, did not, as a rule, harmonize the translations of Ruyl and Van Hasel. Here are two examples.

Where Ruyl translated God with Allah, Van Hasel used Allah-t'alla (with various spellings) 'Allah the Exalted', whereby t'alla reflects one of the most frequently used honorific epithets of Allah in Arabic. Van Hasel uses this phrase also in combinations such, as Radjat Allah-t'alla (often in variation with Radjat Alhatalla) 'kingdom of God'.

Where Ruyl uses půhoon pisang 'banana tree' in Matthew 24:32 as a cultural substitute to render 'fig tree', and pohon kassema for 'fig tree' in the parallel passage in Mark 13:28, Van Hasel uses pohoon ara, a tropical variety of fig trees, in Luke 21:29, the parallel verse of Mark 13:28. 


\section{The Contested Heritage of Ruyl}

Ruyl's pioneering translation work does not just have scholarly relevance for linguistics, history, and translation studies; his translations still have societal relevance and impact. This is because the first Malay gospels by Ruyl contain numerous translational choices that shaped the discourse of Malay-speaking Christians for centuries to come. They also play an important role in current legal, political, and religious battles concerning the use of the word Allah and other religious terms in Indonesian and Malaysian Bibles.

Ruyl's study of the Malay gospels gained considerable societal relevance (and the interest of a much wider public) when the use of Allah by adherents of other religions to denote their $\operatorname{God}(\mathrm{s})$ became the topic of a prolonged religious, legal, and political battle. When the Malaysian government in 2007 prohibited the use of Allah for the Christian God in the Catholic newspaper The Herald, this newspaper went to court and, on $3_{1}$ December 2009, the Mahkamah Tinggi (High Court of Malaysia) ruled that the government decree had been illegal. Not satisfied with this ruling, radical Muslims started riots and churches were set on fire. There was also an attack on a Sikh temple in Kuala Lumpur because the Sikhs have been using Allah in their prayers and Scriptures for centuries. In 2013 another Malaysian court ruled in favour of Muslims who wanted to outlaw non-Islamic use of the word Allah in other faith groups present in Malaysia, not just the Christian communities.

These legal and social struggles surrounding the use of the word Allah in Malaysia have attracted international attention, since the word Allah has also been used for many centuries by Jewish and Christian minorities in Arabspeaking countries to denote their God. The Catholic majority of Malta, too, has used Allah for many centuries, Maltese being a Semitic language just like Arabic and Hebrew, and the Maltese-speaking Church being as old as the Church in Rome and having used Allah for centuries before the birth of Islam.

A complication in the polemic surrounding the use of Allah in Indonesian and Malaysian religious discourse is that Allah in Arabic functions as the name of God-grammatically, it is a proper noun (Thomas 2001:301). In the Hebrew Bible El/Eloh(im), the Semitic cognate of Arabic Allah, is primarily a common noun and not the proper name of the Hebrew God. The Hebrew Supreme Being has a proper name: $J H W H$. Of course, since there is only one God in the Jewish religion, Elohim also has name-like usages in some contexts—but its primary function is as a common noun meaning God (or god[s]).

It was Ruyl who introduced the word Allah into the first Malay Bible translations of the Greek gospels: he used the word Allah to render the Greek theos in Matthew and Mark. Theos is a common noun meaning 'deity' and it is not a 
proper noun. Ruyl's use of Allah as a common noun implied that Allah received the syntactic possibilities of a Malay common noun, for example it could be possessed (Allahku 'my God'), modified by adjectives or relative clauses, and so on. Speakers of Malay with a Muslim background who use Allah as a Malay proper name, in line with its usage in the Quran, will not use it with the modificational possibilities that the word is given in its usage by Malay Christian communities. Some find it even offensive to say or write Allahku, or to use other modifications of the name of God. ${ }^{32}$

Although God has a proper name in the Hebrew Bible, JHWH, the New Testament writers avoid using the proper name of God. He is referred to using theos ('God', translated as Allah) or kurios 'Lord' (translated as Tuhan or tuan by Ruyl) or pater 'Father'. Brouwerius's translation of the Old Testament of 1662 uses both Alla and Deos for the Hebrew common noun El(ohim) 'God'; for example, in Genesis 1 (where only Elohim occurs) both Deos and Alla are used to render Elohim. The proper name JHWH is rendered by Brouwerius with Alla ThAlla.

Brouwerius was not the only Christian translator who chose to use Alla to render the Hebrew Elohim in a language of which the majority of speakers were Muslim: in Africa, the Middle East, and Asia this was standard practice (Thomas 2001:301). Jews or Christians who translated the Old Testament into Arabic used either the Arabic transliteration Yahwah as a proper name of God, or rabb 'Lord', following the Jewish tradition not to utter the holy name of JHWH but to say 'Lord' or 'the Name' when the written text has J HWH (Thomas 2001:302). This Jewish distinction between the qetiv (what is written, JHWH in the consonantal text) and what is spoken when the holy text is read aloud (qere, Adonai 'Lord', or other substitutes such as 'the Name') is also the basis for the choice made in modern standard Malay/Indonesian Bible translations to render the name of God in the Old Testament not with a transliteration of JHWH but as TUHAN (Lord), in capital letters.

It was not uncommon for Muslim writers in the ninth century who quoted New Testament passages in Arabic, to use Allah in their quotations of the New Testament. For example, Ibn Qutayba al-Dinawari of Baghdad quotes Matthew 6:24, where he has Jesus saying: 'You cannot serve both Allah and Mammon' (Thomas 2001:302).

32 The only exception in Malay Bible translation history is the translation of Shellabear and Sulaiman (1910) who, conscious of the Muslim usage of Allah as proper noun, decided to translate the Hebrew name of God, JHWH, with the Arabic name of God, Allah. 
When the presence of Allah in non-Islamic religious texts and discourse was contested in Malaysia in the second half of the twentieth century, Christian and Sikh faith communities in Malaysia had to defend their use of Allah in the religious texts and discourse of their communities more than three centuries after they had started using the term. The Christians put forth several arguments; one of which was that Allah was part of their heritage of many generations, going back all the way to the Bible translation work of Ruyl at the beginning of the seventeenth century (Soesilo 2001b:418). The social and political upheaval surrounding religious discourse and the ownership of religious words thus contributed to a renewed interest of Malaysian and Indonesian Christians in the work of Ruyl, and more generally in the earliest history of Malay-speaking churches and in the ways they talked and wrote in Malay about God and religious issues.

Against this background of renewed scholarly and public interest the Indonesian Bible Society published a volume with articles on Malay Bibles that included a CD with high-quality facsimile editions of all major Malay Bible versions (Mamahit 2014). It included facsimile translations by Ruyl (1629) (Matthew, facsimile of the Utrecht University copy); Ruyl (1638) (Matthew and Mark, Stuttgart copy); Ruyl, Van Hasel, and Heurnius (1651) (Four Gospels and Acts, Utrecht); Brouwerius (1662, Genesis, Utrecht); Brouwerius (1668, New Testament, Utrecht); and Leijdecker, Van der Vorm, Werndly, and Seruys (1733, facsimile of a copy of the Indonesian Bible Society in Jakarta). The title of the volume was 385 tahun Injil Matius terjemahan A.C. Ruyl ( 385 years of the gospel of Matthew translated by A.C. Ruyl). The 4ooth birthday of Ruyl's first Malay gospel of Matthew was celebrated elaborately in both Malaysia and Indonesia. A combination of the search terms Ruyl, terjemahan (translation), and Allah results in thousands of hits, revealing popular interest in this subject on social media, forums, and other web environments.

The legal, social, and political situations with respect to the (inter)religious use of Allah (and other religious terms of Arabic origin) differ in Indonesia and Malaysia. The differences result from the different social, cultural, and political positions of the languages of Malaysian and Indonesian in the two nationstates (Samuel 2010).

From the very beginning of the nationalist independence movement in the first decade of the nineteenth century, bahasa Indonesia (Indonesian) was a key tool of nation-state building, a tool of unification, and a symbol of national unity, a unity rich in religious, linguistic, and cultural diversity. That diversity was a potential (and often real) threat to the very existence of the nation-state of the Republic of Indonesia. The Pancasila constitution was about inclusion and unity: to keep Indonesia intact as a nation-state and to 
prevent religious diversity from degenerating into religious conflicts and 'holy' civil wars. The Republic considered language policy very much as a state affair and this included government institutions concerned with standardization and unification of pronunciation, spelling, and meanings of words, such as the Pusat Bahasa (Language Centre) in Jakarta. A typical example is the inclusivist definition of the lemma Allah in the Kamus besar bahasa Indonesia published by the Pusat Bahasa (Soesilo 20o1b:416): Allah: Nama Tuhan dalam bahasa Arab, pencipta alam semesta yang mahasempurna; Tuhan yang Maha Esa yang disembah oleh orang yang beriman.' (Allah: the name of the Lord in Arabic, the Creator of the universe who is all-perfect; the Only Lord who is worshipped by people of faith.)

In Indonesia there has never been a legal prohibition of the use of the word Allah in Christian Bibles and Allah is accepted as referring to the Supreme Being for all people', according to Soesilo (2001b:416). The position of Malay in Malaysia was (and is) very different: it is strongly associated with the Malay ethnic group, a majority group with Islam as its religion (Samuel 2010). From the perspective of this majority group in Malaysia, Allah is primarily, and, for some, exclusively, an Islamic term, a proper noun, the name of the Most High. This exclusivist perspective is very different from the inclusivist perspective of the word Allah in Indonesia as a term that can be used in interreligious dialogue where shared religious terminology is part of a national language that unites people of different faiths, customs, and cultures.

This does not mean that everyone in Indonesia shares this inclusivist perspective (just as many Malaysian Muslims do not share the exclusivist perspective). For example, there are radical Christians in Indonesia who object to the use of Allah in Christian Bibles because Allah is seen as a pagan god of the Muslims (Soesilo 20o1b:419). They produced an Indonesian Bible called Kitab Suci: Torat dan Injil with the text of Terjemahan baru ${ }^{33}$ but without Allah: all occurrences of Allah had been replaced by the Hebrew word Eloim, also in the New Testament, as a translation of the Greek word theos 'God/god' (Soesilo 20o1b:419).

33 New Translation, published by the Indonesian Bible Society in 1974. This version of the Terjemahan baru that does not use the word Allah was published without the permission of the copyright holder. 


\section{Concluding Remarks}

Thanks to a learned and book-loving, seventeenth-century dean of Lincoln Cathedral, Michael Honywood, we have one copy left of the first Malay gospel of Mark. The voc financed the Mark translation to honour the charters it had with the Dutch Republic. In areas that fell under direct voc authority the voc was expected to protect the public religion and push 'false' religions out of the public domain. This was especially an urgent task in formerly Portuguese areas where Catholic priests such as Franciscus Xaverius had been active as missionaries. The voc translations played a key role in this Protestantization agenda. Given this historical and political context, the term agama Kumpeni 'voc religion' was a rather appropriate contemporary name for this religion.

Ruyl was not a learned scholar, but a remarkably pragmatic voc merchant who employed neologisms, cultural substitutes, and the full richness of Malay as a lingua franca - a language that reflected (and still reflects) the astonishing diversity of the cultural, religious, and economic practices of its millions of speakers in the course of its long history.

Ruyl's translation decisions and strategies laid the foundation for the translation tradition and religious discourses of Malay Christianity that have continued until today, using many terms-including Allah, imam, korban, doa, Roh Kudus, and nabi-that have their origins in Arabic. The Malay and Indonesian translations have spawned hundreds of translations in other languages of the archipelago that also use Allah and other religious terminology of the Malay and Indonesian Bibles, often phonologically adapted to the host languages. Even when there is no Bible translation, these terms have often found their way into the languages of minorities spoken by Christian communities in Asia. For example, when I learned the Papuan language Kombai in the early 1980s, their term for God was Tuanala, a compound of Tuhan 'Lord' and Allah.

The place of Indonesian within the Indonesian nation-state is different from that of Malay in Malaysia because of the different histories of the two countries. This explains the striking differences in perception and acceptance of shared religious terminology, including the word Allah, which was first introduced into Christian Scripture translation by Albert Corneliszoon Ruyl, junior merchant of the Voc at the beginning of the seventeenth century. 


\section{References}

Adelaar, Alexander (2011). Siraya. Retrieving the phonology, grammar and lexicon of a dormant Formosan language. Berlin: Walter de Gruyter.

Boetzelaer van Asperen en C.W.Th. baron van Dubbeldam, (1941). 'Geschiedenis van de Maleische Bijbelvertaling in Nederlandsch-Indië', Bijdragen tot de Taal-, Land-en Volkenkunde 100:27-48.

Collins, James T. (2002). 'A book and a chapter in the history of Malay: Brouwerius's Genesis (1697) and Ambonese Malay', Archipel 67:77-127.

Drewes, M.J. (1948). Van Maleis naar basa Indonesia. [Inaugural speech Leiden University.]

Eijnatten, J. van (2003). Liberty and concord in the United Provinces. Religious toleration and the public in the eighteenth-century Netherlands. Leiden: Brill.

Gossweiler, C. (2014a). '385 tahun Injil Matius terjemahan A.C. Ruyl', in: Neila G.M. Mamahit (ed.), 385 tahun Injil Matius terjemahan A.C. Ruyl. Warisan iman umat Kristiani di Indonesia, pp. x-xxviii. Jakarta: Lembaga Alkitab Indonesia.

Gossweiler, C. (2014b). “'Sesuai kebenaran bahasa Yunani”: Dari perang antara Alkitab Katolik sampai kerja sama ekumenis', in: Neila G.M. Mamahit (ed.), 385 tahun Injil Matius terjemahan A.C. Ruyl. Warisan iman umat Kristiani di Indonesia, pp. 71-86. Jakarta: Lembaga Alkitab Indonesia.

Höweler, C.A. and F.H. Matter (1985). Fontes hymnodiae Neerlandicae impressi 15391700. Nieuwkoop: De Graaf.

Koolen, G.M.J.M. (1993). Een seer bequaem middel. Onderwijs en kerk onder de 17e eeuwse voc. Kampen: Kok.

Mamahit, Neila G.M. (ed.) (2014). 385 tahun Injil Matius terjemahan A.C. Ruyl. Warisan iman umat Kristiani di Indonesia. Jakarta: Lembaga Alkitab Indonesia.

Mooij, J. (1927/1929/1931). Bouwstoffen voor de geschiedenis der protestantsche kerk in Nederlansch Indië. Three volumes. Batavia: Landsdrukkerij.

Niemeijer, H.E. (2002a). 'Orang Nasrani. Protestants Ambon in de zeventiende eeuw', in: G.J. Schutte (ed.), Het Indisch Sion. De gereformeerde kerk onder de Verenigde OostIndische Compagnie, pp. 127-46. Hilversum: Verloren.

Niemeijer, H.E. (2002b). 'Agama Kumpeni? Ternate en de protestantisering van de Noord-Molukken en Noord-Sulawesi 1627-1795', in: G.J. Schutte (ed.), Het Indisch Sion. De gereformeerde kerk onder de Verenigde Oost-Indische Compagnie, pp. 14776. Hilversum: Verloren.

Niemeijer, H.E., Th. van den End and G.J. Schutte (2015). Bronnen betreffende de geschiedenis van kerk en school in de gouvernementen Ambon, Ternate en Banda ten tijde van de Verenigde Oost-Indische Compagnie, 1605-1791. Volume I, Band 2. Gouvernement Ambon, 169o-1791. The Hague: Huygens ING.

Niemeijer, H.E., Th. van den End and G.J. Schutte (2015). Bronnen betreffende de 
geschiedenis van kerk en school in de gouvernementen Ambon, Ternate en Banda ten tijde van de Verenigde Oost-Indische Compagnie, 1605-1791. Volume IV. Inleiding, bijlagen en registers, gebiedskaarten, illustraties. The Hague: Huygens ING.

Ogden, G. (2001). 'Bible translation', in: Scott W. Sunquist (ed.), A dictionary of Asian Christianity, p. 79. Grand Rapids, MI: Eerdmans.

Rooden, P. van (1996). Religieuze regimes. Over godsdienst en maatschappij in Nederland, 1570-1990. Amsterdam: Bert Bakker.

Samuel, J. (2010). 'Les voies de l'aménagement linguistique dans le monde malayophone', Télescope 16-3:135-55.

Schutte, G.J. (2002). 'De kerk onder de Compagnie', in: Schutte, G.J. (ed.) (2002). Het Indisch Sion. De gereformeerde kerk onder de Verenigde Oost-Indische Compagnie, pp. 43-64. Hilversum: Verloren.

Schutte, G.J. (ed.) (2002). Het Indisch Sion. De gereformeerde kerk onder de Verenigde Oost-Indische Compagnie. Hilversum: Verloren.

Soesilo, D. (2001a). Mengenal Alkitab anda. Jakarta: Lembaga Alkitab Indonesia.

Soesilo, D. (2001b). 'Translating the names of God: Recent experience from Indonesia and Malaysia', The Bible Translator 52:414-23.

Soesilo, D. (2007). 'Bible translation in Asia-Pacific and Americas', in: Philip Noss (ed.), $A$ history of Bible translation, pp. 163-85. Rome: Edizione di Storia e Letteratura.

Soesilo, D. (2013). 'Celebrating 400 years of Ruyl's Malay translation of Matthew's gospel', The Bible Translator 64:173-84.

Swellengrebel, J.L. (1974). In Leijdeckers voetspoor. Anderhalve eeuw Bijbelvertaling en taalkunde in de Indonesische talen. Volume I 1820-1900. Amsterdam/Haarlem: Nederlands Bijbelgenootschap.

Thomas, K.J. (2001). 'Allah in translations of the Bible', The Bible Translator 52:301-6. Venables, Edmund (1885). 'Honywood, Michael', Dictionary of National Biography 27:250-1. London: Smith, Elder \& Co.

Vries, Lourens de (2002). 'Van vijg tot pisang: De eerste Maleise bijbelvertaling van 1629', Met Andere Woorden 3:3-9.

Vries, Lourens de (2005). 'The fig that became a banana: The first period of Bible translation in Indonesia (1629-1811)', in: Supardan (ed.), One Bible many versions, pp. 13-25. Bogor: Indonesian Bible Society.

Vries, Lourens de (2009). 'Ikhtisar sejarah penerjemahan Alkitab di Indonesia', in: Henri Chambert-Loir (ed.), Sadur. Sejarah terjemahan di Indonesia dan Malaysia, pp. 45988. Jakarta: Gramedia.

Vries, Lourens de (2014). 'Bersalin kapada Bassa Malaju'. Penerjemahan Alkitab di Nusantara Pada Abad ke-17 dan ke-18' In N.G.M. Mamahit (ed.), 385 Tahun Injil Matius Terjemahan A.C. Ruyl. Jakarta: Lembaga Alkitab Indonesia, pp. $45^{-58}$.

Vries, Lourens de (2016). 'The book of true civilization: The origins of the Bible Society Movement in the Age of Enlightenment', The Bible Translator 67-3:331-50. 
Werndly, G.H. (1736). Maleische spraakkunst uit de eige schriften der Maleiers opgemaakt; met eene voorreden en een dubbel aanhangsel van twee boekzalen van boeken, in deze tale zo van Europeers, als van Maleiers geschreven. Amsterdam: Wetstein. 